\title{
MENULIS DESKRIPSI DENGAN MODEL INVESTIGASI KELOMPOK
}

\author{
(WRITING DESCRIPTION WITH THE MODEL OF GROUP \\ INVESTIGATION)
}

\author{
Ridwan \\ Fakultas Sastra dan Budaya, Universitas Khairun \\ Jalan Kampus, Kelurahan Gambesi, Ternate Selatan \\ E-mail: ridho8983@yahoo.co.id \\ Telepon 085237313276
}

\begin{abstract}
Writing is the way to transform an idea or message to the readers. The act of writing in this research is descriptive writing. The descriptive writing aims to write an object so the reader can feel and see the object by themselves. This research is known as class action research. The class action research is conducted by using group investigation learning model: the PTK action comprisies two cycles, every cycle consists of three times of meetings. Every cycle includes planning, action, reflection, and evaluation. The results of the research show that the group investigation learning model could improve descriptive writing skills of Indonesian letter studies. These things are shown in the learning process until evaluation.
\end{abstract}

Keywords: writing, descriptive, group investigation

\begin{abstract}
Abstrak
Menulis adalah cara mentransformasikan suatu ide atau pesan kepada pembaca. kegiatan menulis dalam penelitian ini adalah menulis deskriptif. Menulis deskriptif bertujuan untuk menulis objek sehingga pembaca dengan sendirinya dapat merasakan dan melihat objek tersebut. Penelitian ini dikenal dengan penelitian tindakan kelas. Penelitian tindakan kelas dilakukan dengan menggunakan model pembelajaran investigasi: tindakan PTK terdiri dari dua lingkaran. Setiap lingkaran terdiri atas tiga kali pertemuan. Setiap lingkaran mencakup perencanaan, tindakan, refleksi, dan evaluasi. Hasil penelitian menunjukkan bahwa model pembelajaran investigasi kelompok dapat meningkatkan kemampuan menulis deskriptif terhadap studi menulis surat bahasa Indonesia. Hal ini ditunjukkan dalam proses pembelajaran sampai pada evaluasi.
\end{abstract}

Kata kunci: menulis, deskriptif, investigasi kelompok.

\section{Pendahuluan}

Keterampilan berbahasa terdiri atas empat komponen, yaitu keterampilan menyimak, berbicara, membaca, dan menulis. Berdasarkan bentuknya, keterampilan berbahasa dapat dibedakan ke dalam dua bagian, yakni keterampilan berbahasa lisan dan keterampilan berbahasa tulis. Keterampilan berbahasa lisan meliputi keterampilan menyimak dan keterampilan berbicara. Keterampilan berbahasa tulis meliputi keterampilan membaca dan keterampilan menulis. Berdasar- 
kan sifatnya, keterampilan berbahasa dapat dibedakan menjadi keterampilan berbahasa reseptif (menyimak dan membaca) dan keterampilan berbahasa produktif (berbicara dan menulis).

Menulis merupakan salah satu kemampuan yang perlu dimiliki oleh siswa sejak mulai sekolah dasar sampai dengan perguruan tinggi. Dengan memiliki kemampuan menulis, cakrawala berpikir kreatif dan kritis siswa/mahasiswa dapat berkembang. Keterampilan menulis merupakan salah satu keterampilan yang perlu dimiliki oleh siswa/mahasiswa untuk melanjutkan studi mereka ke lembaga pendidikan yang lebih tinggi ataupun untuk terjun ke masyarakat.

Menulis adalah kegiatan penyampaian pesan (gagasan, perasaan, dan informasi) secara tertulis kepada pihak lain, baik dalam bentuk verbal maupun nonverbal (Suparno dan Yunus, 2002: 13). Pentingnya pembelajaran menulis dapat dilihat dari beberapa hasil penelitian antara lain sebagai berikut. Pertama, penelitian Laboh (2005: 45) menunjukkan bahwa strategi guru atau dosen dalam pembelajaran menulis kreatif masih bersifat klasikal (penyampaian bersifat lisan) atau belum terlaksana sesuai dengan model pembelajaran Kurikulum Berbasis Kompetensi (KBK) sehingga masih diperlukan penyesuaian (adaptasi). Kedua, penelitian Kadir (2005) menunjukkan bahwa materi pembelajaran disajikan oleh guru dan dosen melalui dua macam strategi, yaitu (1) materi pelajaran didiktekan sendiri dan (2) materi diambil dari satuan pelajaran dan disusun dalam bentuk satuan pelajaran.

Sehubungan dengan fakta tersebut, diduga dosen masih beranggapan bahwa kemampuan mahasiswa berpikir secara individual dalam konteks pembelajaran yang bersifat klasikal merupakan faktor utama untuk mencapai keberhasilan mahasiswa. Dosen belum memberdayakan kelompok kecil dalam kelas, mahasiswa tidak diberi tanggung jawab sepenuhnya tentang tugas yang diberikan, penilaian terhadap hasil kerja mahasiswa terkadang tidak dikembalikan oleh dosen, dan dosen sangat jarang menerapkan teknik diskusi dalam bentuk kelompok-kelompok kecil yang bersifat heterogen. Dengan demikian, mahasiswa tidak terbiasa berpikir kritis, bekerja sama, atau saling mengajari dalam proses pembelajaran.

Studi pendahuluan yang telah dilakukan pada bulan Februari 2011 di Unkhair, khususnya pada Program Studi Sastra Indonesia, menunjukkan bahwa (1) keterampilan menulis mahasiswa masih rendah; (2) minat belajar mahasiswa masih minim; (3) variasi pembelajaran yang diterapkan oleh dosen masih bersifat klasikal sehingga menimbulkan kejenuhan mahasiswa; dan (4) kurangnya disiplin dalam proses pembelajaran.

Untuk mengantisipasi masalah tersebut, banyak pilihan yang dapat dilaksanakan, yaitu variasi dosen dalam pembelajaran dengan menerapkan metode yang sesuai. Sehubungan perkembangan model pembelajaran, salah satu model pembelajaran ialah pembelajaran kooperatif. Pembelajaran kooperatif dikenal bermacam-macam model, salah satu modelnya investigasi kelompok (group investigation). Oleh karena itu, model investigasi kelompok merupakan salah satu solusi yang diterapkan dalam pembelajaran menulis, khususnya pada mahasiswa Sastra Indonesia melalui penelitian tindakan kelas.

Masalah dalam penelitian ini adalah apakah model investigasi kelompok dapat meningkatkan keterampilan menulis deskripsi pada mahasiswa Sastra Indonesia angkatan 2010 Universitas Khairun Ternate? Adapun tujuan penelitian ini adalah untuk meningkatkan keterampilan menulis deskripsi mahasiswa Sastra Indonesia angkatan 2010 Unkhair dengan model investigasi kelompok. 


\section{Tinjauan Pustaka}

\subsection{Pembelajaran Menulis Deskripsi}

Menulis merupakan suatu cara untuk mengetahui dan menemukan apa yang diketahui oleh seseorang yang terekam dalam pikirannya (Cox, 1998: 309). Menulis dan proses berpikir berkaitan erat dalam menghasilkan suatu karangan yang baik. Karangan yang baik merupakan manifestasi dari keterlibatan proses berpikir. Dengan demikian, proses berpikir sangat menentukan lahirnya suatu karangan yang berkualitas. Syafi'ie (1988: 43) mengemukakan bahwa salah satu substansi retorika menulis adalah penalaran yang baik.

Pappas dkk. (1995: 215) mengemukakan bahwa menulis sebagai proses berpikir merupakan aktivitas yang bersifat aktif, konstruktif, dan penuangan makna. Pada saat menulis, mahasiswa dituntut berpikir untuk menuangkan gagasannya berdasarkan skemata, pengetahuan, dan pengalaman yang dimiliki secara tertulis. Rangkaian aktivitas menulis adalah sebagaimana yang dikemukakan oleh Tompkins (1994: 126), yakni pramenulis, pengedrafan, perbaikan, penyuntingan, dan publikasi.

Ragam tulisan dilihat dari segi bentuk dan cara pengungkapannya dapat dibagi atas narasi, deskripsi, eksposisi, persuasi, dan argumentasi. Dari kelima ragam itu, dalam penelitian ini ragam tulisan yang menjadi objek penelitian adalah kemampuan mahasiswa menulis deskripsi.

Menurut Tompkins (1994: 111) deskripsi merupakan karangan yang mengggambarkan sesuatu melalui kata-kata. Jadi, deskripsi merupakan wacana yang membantu kita memvisualisasikan sesuatu. Fokusnya pada penampakan suatu objek sehingga kita dapat melihatnya secara tepat (Temple, 1988: 136). Dengan kata lain, deskripsi adalah tulisan yang memaparkan rincian atau detail tentang suatu objek sehingga imaji- nasi dan sensitivitas pembaca/pendengar bagaikan melihat, mendengarkan, merasakan, atau mengalami langsung objek atau peristiwa tersebut.

Smalley,dkk. (2001:3) menyatakan bahwa tahapan proses menulis itu meliputi pramenulis, membuat draf (menulis), dan merevisi. Sehubungan dengan hal tesebut, Akhadiah, dkk. (1998: 2) menyatakan bahwa kegiatan menulis adalah suatu proses. Dalam proses tersebut terdapat tahapan kegiatan yang dilakukan untuk menghasilkan tulisan yang baik. Adapun tahap-tahap menulis tersebut diuraikan sebagai berikut.

\section{a. Tahap Pembelajaran Pramenulis}

Pembelajaran pramenulis merupakan segala sesuatu yang terjadi sebelum proses penulisan yang meliputi menggali ide, mengingat, dan memunculkannya serta menghubung-hubungkan ide dan sejenisnya. Fokus pembelajaran pada tahap pramenulis meliputi (1) pencurahan topik sesuai dengan tema (brainstroming), (2) pemilihan topik, (3) pengembangan topik, (4) penulisan judul, dan (5) penyusunan kerangka karangan.

\section{b. Tahap Pembelajaran Pengedrafan}

Pada tahap ini mahasiswa mengembangkan kerangka karangan yang telah disusun berdasarkan topik ke dalam draf. Dalam hal ini, mahasiswa mengorganisasikan dan mengembangkan ide yang telah diperolehnya pada kegiatan curah pendapat. Dengan kata lain, mahasiswa mengembangkan gagasan pokok dan detail penjelasnya dalam bentuk rangkaian kalimat dan paragraf dengan selalu memperhatikan tema dan topik. Penyusunan draf ditekankan pada aspek isi dan bukan pada spek mekanik. Jadi, permasalahan pokok dalam tahap pembelajaran pengedrafan ini adalah bagaimana membantu atau membimbing mahasiswa 
sehingga dapat mengembangkan gagasan pokok dan detail-detail penjelasnya ke dalam rangkaian kalimat dan paragraf yang dapat terpahami dengan baik. Adapun langkah-langkahnya adalah sebagai berikut, yaitu (1) mahasiswa membaca model teks deskripsi secara kelompok atau individu, (2) dosen mengarahkan mahasiswa menjawab pertanyaan yang berkaitan dengan rincian detail topik dalam bacaan, (3) mahasiswa menulis/membaca kalimat demi kalimat dengan teliti dan (4) tiap kelompok melaporkan hasil kerja kelompoknya.

Setelah selesai proses pengenalan model teks, mahasiswa menulis draf berdasarkan kerangka yang telah disusun ke dalam paragraf sampai akhirnya menghasilkan draf awal yang bersifat sementara. Kemudian, dilanjutkan dengan tahap perbaikan dan penyuntingan.

\section{c. Tahap Pembelajaran Perbaikan}

Pada tahap pembelajaran perbaikan ini mahasiswa menata ulang kerincian dan kejelasan penggambaran objek dalam draf dengan cara mengganti, menambah, menghilangkan, mengganti, atau menghilangkan; kata/kalimat yang tidak sempurna, kurang tepat melalui perbaikan kesejawatan, baik secara kelompok kecil atau berpasangan serta balikan langsung dari dosen.

\section{d. Tahap Pembelajaran Penyuntingan}

Tahap penyuntingan draf karangan merupakan salah satu proses menulis yang perlu dialami mahasiswa agar tulisannya dapat lebih baik. Fokus pembelajaran penyuntingan menyangkut aspek mekanik draf. Aspek mekanik tersebut antara lain (1) penulisan huruf kapital, (2) penulisan kata dasar, kata ganti, kata depan, dan lain-lain, (3) pemenggalan kata, dan (4) pemakaian tanda baca; titik, koma, titik koma, seru, tanya, dan lainlain. Dengan demikian, dalam pembelajaran penyuntingan menyangkut bagaimana stra- tegi membimbing mahasiswa sehingga dapat memperbaiki kesalahan penulisan pemenggalan, dan pemakaian tanda baca dengan benar berdasarkan kaidah EYD.

\section{e. Tahap Pembelajaran Publikasi}

Setelah semua tahap terlewati sebagai suatu proses, pada tahap akhir adalah publikasi. Mahasiswa mempublikasikan karangannya melalui kegiatan berbagi hasil tulisan (sharing). Kegiatan ini dilakukan untuk memperoleh masukan terhadap hasil karangan mahasiswa. Masukan dapat diperoleh dalam kelompok atau dari dosen. Kegiatan berbagi hasil ini dapat dilakukan, antara lain, dengan menugasi mahasiswa untuk membacakan hasil karangannya di depan kelas (Tompkins, 1994: 127).

Tahap publikasi memberikan kesempatan calon pembaca mentransformasi tulisan dan sebagai penghargaan kepada penulis untuk mengenalkan hasil kerjanya. Publikasi juga menunjukkan pencapaian dan kemajuan unjuk kerja menulis untuk disampaikan kepada orang tua.

\subsection{Hakikat Model Investigasi Kelompok}

Model investigasi kelompok dalam penelitian ini merupakan salah satu bentuk pembelajaran kooperatif dengan memaksimalkan keterlibatan mahasiswa selama pembelajaran menulis deskripsi berlangsung. Kelebihan model investigasi kelompok adalah (1) meningkatkan motivasi belajar mahasiswa yang tinggi, (2) porsi keterlibatan mahasiswa sangat banyak, dan (3) mahasiswa merasa tidak jenuh dan tidak mengada-ada dalam menulis sebab bersumber dari hasil investigasinya. Selain itu, metode ini akan memberikan dampak pengiring kepada mahasiswa, seperti dengan terjadinya pembelajaran lintas bidang studi.

Apabila dilihat dari segi kekurangan atau kelemahan teknik tersebut, dapat dikatakan bahwa teknik ini memerlukan waktu 
yang banyak karena harus memberikan kesempatan kepada mahasiswa untuk melakukan penyelidikan (investigasi) secara saksama, kemudian hasil investigasi tersebut dituangkan dalam bentuk tulisan. Selain itu, di dalam menerapkan metode ini, dosen harus memiliki persiapan atau perencanaan yang matang agar setiap penyelidikan atau investigasi yang dilakukan dapat menjadi sebuah proses pembelajaran.

Penerapan metode pembelajaran ini memiliki karakteristik, antara lain, adalah (1) tujuan yang luas dan menyeluruh, (2) tidak menekankan pada hasil tulisan, tetapi proses tulisan, (3) perencanaan dilakukan secara demokratis bersama mahasiswa, dan (4) seluruh kegiatan berpusat pada mahasiswa. Dengan karaktristik seperti itu akan dapat memberikan banyak nilai tambah sebagai pengembangan kemampuan menulis mahasiswa, seperti (1) secara tidak langsung terjadi proses pembelajaran mata kuliah lain dan pembahasan aspek pembelajaran lainnya secara terencana dan sistematis; (2) dapat memupuk keberanian, pikiran ilmiah, sikap kritis, dan analitik mahasiswa; (3) dapat menimbulkan dampak pengiring yang positif seperti; belajar diskusi, berbicara, wawancara, menyurvei, belajar bekerja sama, bertanggung jawab dalam kelompok, dan memupuk sikap demokratis. Di samping hal-hal tersebut, model ini juga memberikan pembimbingan riil secara optimal kepada mahasiswa sehingga sangat memungkinkan interaksi pembelajaran yang menyenangkan. Namun, menurut Ibrahim (2006:23), model investigasi kelompok adalah model pembelajaran kooperatif yang paling kompleks dan paling sulit untuk diterapkan.

\subsection{Langkah-Langkah Model Investigasi Kelompok}

\begin{tabular}{|c|c|}
\hline Fase & Tingkah laku dosen \\
\hline $\begin{array}{l}\text { Fase } 1 \\
\text { Mengidentifikasikan topik dan } \\
\text { mengatur mahasiswa ke dalam } \\
\text { kelompok }\end{array}$ & $\begin{array}{l}\text { 1. Para mahasiswa meneliti beberapa } \\
\text { sumber, mengusulkan sejumlah topik, } \\
\text { dan mengategorikan saran-saran. } \\
\text { 2. Para masiswa bergabung dengan } \\
\text { kelompoknya untuk mempelajari topik } \\
\text { yang telah mereka pilih. } \\
\text { 3. Komposisi kelompok didasarkan pada } \\
\text { ketertarikan mahasiswa dan harus } \\
\text { bersifat heterogen. } \\
\text { 4. Dosen membantu dalam } \\
\text { mengumpulkan informasi dan } \\
\text { memfasilitasi pengaturan. }\end{array}$ \\
\hline $\begin{array}{l}\text { Fase } 2 \\
\text { Merencanakan tugas yang akan } \\
\text { dipelajari }\end{array}$ & $\begin{array}{l}\text { Para mahasiswa merencakan bersama } \\
\text { mengenai: } \\
\text { 1. Apa yang kita pelajari? } \\
\text { 2. Bagaimana kita mempelajarinya? Siapa } \\
\text { melakukan apa? (pembagian tugas) } \\
\text { 3. Untuk tujuan atau kepentingan apa } \\
\text { kita mengivestigasi topik ini? }\end{array}$ \\
\hline
\end{tabular}




\begin{tabular}{|c|c|}
\hline $\begin{array}{l}\text { Fase } 3 \\
\text { Melaksanakan investigasi }\end{array}$ & $\begin{array}{l}\text { 1. Para mahasiswa mengumpulkan } \\
\text { informasi, menganalisis data, dan } \\
\text { membuat kesimpulan. } \\
\text { 2. Tiap anggota kelompok berkontribusi } \\
\text { untuk usaha-usaha yang dilakukan } \\
\text { kelompoknya. } \\
\text { 3. Para mahasiswa saling bertukar, } \\
\text { berdiskusi, mengklarifikasi, dan } \\
\text { mensintesis semua gagasan. }\end{array}$ \\
\hline $\begin{array}{l}\text { Fase } 4 \\
\text { Menyiapkan laporan akhir }\end{array}$ & $\begin{array}{l}\text { 1. Anggota kelompok menentukan pesan- } \\
\text { pesan esensial dari proyek mereka. } \\
\text { 2. Anggota kelompok merencanakan apa } \\
\text { yang akan mereka laporkan, dan } \\
\text { bagaimana mereka akan membuat } \\
\text { presentasi mereka. } \\
\text { 3. Wakil-wakil kelompok membentuk } \\
\text { sebuah panitia acara untuk } \\
\text { mengkoordinasikan rencana-rencana } \\
\text { presentasi. }\end{array}$ \\
\hline $\begin{array}{l}\text { Fase } 5 \\
\text { Mempresentasikan laporan } \\
\text { akhir }\end{array}$ & $\begin{array}{l}\text { 1. Presentasi yang dibuat untuk seluruh } \\
\text { kelas dalam berbagai macam bentuk. } \\
\text { 2. Bagian presentasi tersebut harus dapat } \\
\text { melibatkan pendengarnya secara aktif. } \\
\text { 3. Para pendengar tersebut mengevaluasi } \\
\text { kejelasan dan penampilan presentasi } \\
\text { berdasarkan kriteria yang telah } \\
\text { ditentukan sebelumnya oleh seluruh } \\
\text { anggota kelas. }\end{array}$ \\
\hline $\begin{array}{l}\text { Fase } 6 \\
\text { Evaluasi }\end{array}$ & $\begin{array}{l}\text { 1. Para mahasiswa saling memberi } \\
\text { umpan balik mengenai topik tersebut, } \\
\text { mengenai tugas yang mereka kerjakan, } \\
\text { mengenai keefektifan pengalaman- } \\
\text { pengalaman mereka. } \\
\text { 2. Dosen dan mahasiswa berkolaborasi } \\
\text { dalam mengevaluasi pembelajaran } \\
\text { mahasiswa. } \\
\text { 3. Penilaian atas pembelajaran harus } \\
\text { mengevaluasi pemikiran paling tinggi. }\end{array}$ \\
\hline
\end{tabular}

(Sumber: Slavin, 2005: 218--220)

Keenam tahap/fase model investigasi kelompok peneliti kembangkan kemudian peneliti tambahkan dan kurangi beberapa aktivitas pembimbingan bagi dosen dalam tiap-tiap fase serta peneliti pertahankan langkah-langkah yang peneliti anggap relevan.

\section{Metode Penelitian}

Penelitian ini adalah termasuk Penelitian Tindakan Kelas (PTK) atau clasroom action research. PTK merupakan suatu penelitan yang berorientasi pada usaha mencari solusi 
secara praktis terhadap permasalahan yang dihadapi atau memperbaiki pelaksanan KBM (Purwadi dalam Sukidin dkk, 2002:10). Jenis penelitian ini berdasarkan pada sifat dan karakternya adalah (1) situasional, (2) kontekstual, (3) kolaboratif, (4) Self-reflective dan self-evaluative, dan (5) fleksibel.

\subsection{Desain Penelitian}

Penelitian ini dilaksanakan selama delapan minggu efektif. Minggu pertama diisi dengan kegiatan sosialisasi, tes pratindakan, dan simulasi pembelajaran model investigasi kelompok dalam pembelajaran menulis deskripsi. Minggu kedua sampai dengan minggu delepan diisi dengan kegiatan pembelajaran menulis deskripsi dengan penerapannya dilaksanakan selama 2 siklus. Siklus pertama dilaksanakan selama tiga kali proses pembelajaran, siklus kedua dilaksanakan selama tiga kali proses pembelajaran. Pada setiap akhir siklus diadakan evaluasi. Waktu yang digunakan pada setiap pertemuan selama 2 x 50 menit, sesuai dengan jam pelajaran yang berlaku di Program Studi Sastra Indonesia, Fakultas Sastra dan Budaya, Universitas Khairun Ternate.

Pelaksanaan penelitian dilakukan berdasarkan model penelitian tindakan kelas yang dikembangkan oleh Kemmis dan Mc Taggart (dalam Kunandar 2008: 70) yang diawali dengan perencanaan, tindakan, pengamatan, dan refleksi.

\subsection{Instrumen Penelitian}

Instrumen pada penelitian ini adalah peneliti sendiri sebagai instrumen kunci. Sebagai seorang peneliti tentunya harus (1) terkait pada kode etik penelitian, (2) berorientasi pada tujuan penelitian, (3) bertindak secara objektif, dan (4) berorientasi pada kebenaran.

Instrumen penunjang yang peneliti gunakan adalah pedoman observasi, pedoman wawancara, dan tes menulis deskripsi.

\subsection{Data dan Sumber Data}

Data penelitian ini berupa tindakan dan hasil yang diperoleh melalui observasi, wawancara, catatan lapangan, dokumentasi, dan karangan mahasiswa. Data ini berkaitan dengan perencanaan, pelaksanaan, dan penilaian pembelajaran menulis deskripsi melalui implementasi model investigasi kelompok mahasiswa Sastra Indonesia angkatan 2010 Universitas Khairun Ternate.

Sumber data penelitian ini adalah dosen dan mahasiswa dalam kegiatan proses belajar-mengajar pembelajaran menulis deskripsi dengan implementasi model investigasi kelompok yang berlangsung di Program Studi Sastra Indonesia angkatan 2010 Universitas Khairun, yang terdiri atas delapan mahasiswa.

\subsection{Teknik Pengumpulan Data}

Peneliti melaksanakan pengumpulan data melalui empat teknik, yaitu (1) observasi, (2) pencatatan data, (3) wawancara, dan (4) studi dokumentasi.

\subsection{Teknik Analisis Data}

Data yang diperoleh melalui bentuk tes akan dianalisis dengan statistik deskriptif, sedangkan data yang diperoleh dengan nontes akan dianalisis dengan mengadopsi analisis Miles dan Huberman (1992). Data yang diperoleh dari hasil penelitian ini dianalisis dengan tiga tahap kegiatan yang terjadi secara bersamaan, yaitu reduksi data, penyajian data, dan penarikan kesimpulan atau verifikasi

Indikator penilaian menulis yang digunakan adalah penilaian yang diadopsi dari pendapat Nurgiantoro (2009: 306--307). Indikator tersebut diuraikan dalam tabel berikut. Indikator ketuntasan belajar mahasiswa atau standar kelulusan mahasiswa dikatakan berhasil apabila kemampuan menulis deskripsi mahasiswa berada pada kategori sedang. 
Tabel 1

Aspek Penilaian Menulis Deskripsi

\begin{tabular}{|c|l|c|c|c|c|c|c|}
\hline No. & \multicolumn{1}{|c|}{ Butir Penilaian } & $\mathbf{1}$ & $\mathbf{2}$ & $\mathbf{3}$ & $\mathbf{4}$ & $\mathbf{5}$ & Skor \\
\hline 1 & Isi gagasan & & & & & & \\
\hline 2 & Organisasi isi & & & & & & \\
\hline 3 & Tata bahasa & & & & & & \\
\hline 4 & Diksi dan ejaan & & & & & & \\
\hline
\end{tabular}

\begin{tabular}{lll}
\hline No. & Skor & Kategori \\
\hline 1 & 5 & Baik sekali \\
2 & 4 & Baik \\
3 & 3 & Sedang \\
4 & 2 & Kurang \\
5 & 1 & Kurang sekali \\
\hline
\end{tabular}

\begin{tabular}{ll} 
Nilai $\quad$ Skor yang diperoleh \\
\hdashline- Skor maksimal $^{-}$
\end{tabular}

\section{Pembahasan}

\subsection{Deskripsi Proses Pratindakan}

PTK ini diawali dengan mengobservasi kampus dan kelas yang dijadikan sebagai subjek penelitian. Setelah itu, diadakan sosialisasi mengenai penerapan model investigasi kelompok dalam meningkatkan pembelajaran menulis deskripsi mahasiswa Sastra Indonesia angkatan 2010. Sebelum diberikan tindakan pembelajaran, terlebih dahulu diadakan tes pratindakan untuk memperoleh gambaran kompetensi awal mahasiswa dalam menulis deskripsi yang meliputi isi gagasan, organisasi isi, tata bahasa, diksi, dan ejaan.

Setelah tes pratindakan dilakukan, peneliti melaksanakan simulasi penerapan model investigasi kelompok dalam meningkatkan pembelajaran menulis deskripsi mahasiswa Sastra Indonesia angkatan 2010 dalam pembelajaran menulis dengan penekanan unsur yang meliputi isi gagasan, organisasi isi, tata bahasa, diksi, dan ejaan. Penerapan model investigasi kelompok dalam meningkatkan pembelajaran rnenulis deskripsi mahasiswa diawali dengan penyampaian tujuan pembelajaran dan memotivasi mahasiswa, menyajikan informasi tentang materi pembelajaran dan tugas-tugas, mengorganisasikan mahasiswa dalam kelompok-ke-lompok kecil terdiri atas 3-4 mahasiswa setiap kelompok, membantu mahasiswa dalam belajar kelompok, mengetes kompetensi menulis deskripsi, dan memberikan penghargaan atau penguatan kepada mahasiswa atau kelompok yang kompetensi menulis deskripsinya memenuhi standar. 
Tabel 2

Hasil Tes Pratindakan Ketepatan Isi Gagasan, Ketepatan Organisasi Isi, Ketepatan Tata Bahasa, Diksi, dan Ejaan Menulis Deskripsi Mahasiswa Sastra Indonesia Angkatan 2010

\begin{tabular}{|c|c|c|c|c|c|l|}
\hline No. & $\begin{array}{c}\text { Kode } \\
\text { Subjek }\end{array}$ & $\begin{array}{c}\text { Isi } \\
\text { Gagasan }\end{array}$ & $\begin{array}{c}\text { Organisasi } \\
\text { Isi }\end{array}$ & $\begin{array}{c}\text { Tata } \\
\text { Bahasa }\end{array}$ & $\begin{array}{c}\text { Diksi } \\
\text { dan } \\
\text { Ejaan }\end{array}$ & \multicolumn{1}{|c|}{ Keterangan } \\
\hline $\mathbf{1}$ & $\mathbf{2}$ & $\mathbf{3}$ & $\mathbf{4}$ & $\mathbf{5}$ & $\mathbf{6}$ & \multicolumn{1}{|c|}{$\mathbf{7}$} \\
\hline 1 & 201001 & 4 & 5 & 4 & 5 & 4,5 (baik) \\
\hline 2 & 201002 & 3 & 4 & 3 & 3 & 3,25 (sedang) \\
\hline 3 & 201003 & 2 & 3 & 4 & 4 & 3,25 (sedang) \\
\hline 4 & 201004 & 3 & 1 & 3 & 3 & 2,5 (kurang) \\
\hline 5 & 201005 & 1 & 3 & 2 & 2 & 2 (kurang) \\
\hline 6 & 201006 & 2 & 1 & 1 & 1 & $\begin{array}{l}1,25 \text { (kurang } \\
\text { sekali) }\end{array}$ \\
\hline 7 & 201007 & 1 & 2 & 2 & 2 & $\begin{array}{l}1,75 \text { (kurang } \\
\text { sekali) }\end{array}$ \\
\hline 8 & 201008 & 1 & 2 & 1 & 1 & $\begin{array}{l}1,25 \text { (kurang } \\
\text { sekali) }\end{array}$ \\
\hline
\end{tabular}

Berdasarkan hasil tes pratindakan tersebut, dari 8 subjek penelitian, 1 orang mendapatkan kategori baik, 2 orang kategori sedang, 2 orang kategori kurang, dan 3 orang kategori kurang sekali. Berdasar dari tes tersebutlah, penelitian tindakan akan dilaksanakan dengan menggunakan model pembelajaran investigasi kelompok. Kegiatan PTK dilaksanakan karena keterampilan menulis deskripsi mahasiswa Sastra Indonesia angkatan 2010 masih rendah.

\subsection{Deskripsi Proses Siklus Pertama}

\section{a) Perencanaan}

Perencanaan dalam PTK ini yang harus dilakukan adalah persiapan proses belajarmengajar dalam bentuk program rencana pembelajaran dan rencana kegiatan yang dilakukan oleh peneliti, dosen, dan mahasiswa.

Kegiatan peneliti adalah sebagai berikut: (1) menyusun kisi-kisi pedoman pembuatan ren-cana pembelajaran, (2) berkolaborasi dengan dosen menyusun SAP, (3) membantu dosen dalam pelaksanaan pembelajaran di kelas, (4) berkolaborasi dengan dosen melakukan tes siklus pertama, dan (5) menganalisis hasil tes siklus pertama.

Kegiatan dosen adalah sebagai berikut: (1) bersama peneliti menyusun SAP, (2) melakukan aktivitas pembelajaran sesuai dengan petunjuk dalam rencana pembelajaran, (3) dosen bersama peneliti melakukan tes siklus pertama, (4) menilai hasil tes siklus pertama, (5) memberikan umpan balik tentang hasil tes mahasiswa, dan (6) memberikan penghargaan kepada mahasiswa atau kelompok yang kompetensi menulisnya memenuhi standar.

Kegiatan mahasiswa adalah sebagai berikut: (1) mengikuti kegiatan pembelajaran, (2) menyelesaikan tugas-tugas pembelajaran, dan (3) menerima umpan balik dari dosen. 
b) Tindakan

Pelaksanaan pembelajaran menulis deskripsi pada siklus pertama dengan menggunakan model investigasi kelompok masih mengalami berbagai kekurangan, di antaranya adalah masih adanya mahasiswa yang

c) Evaluasi kurang aktif dalam melakukan investigasi, belum mampu menyusun karangan dengan tepat, dan masih adanya mahasiswa yang tidak mengetahui pilihan kata yang tepat sesuai dengan tema tulisan.

Tabel 3

Hasil Tes Siklus I Ketepatan Isi Gagasan, Ketepatan Organisasi Isi, Ketepatan Tata Bahasa, Diksi, dan Ejaan Menulis Deskripsi Mahasiswa Sastra Indonesia Angkatan 2010

\begin{tabular}{|c|c|c|c|c|c|l|}
\hline No. & $\begin{array}{c}\text { Kode } \\
\text { Subjek }\end{array}$ & $\begin{array}{c}\text { Isi } \\
\text { Gagasan }\end{array}$ & $\begin{array}{c}\text { Organisasi } \\
\text { Isi }\end{array}$ & $\begin{array}{c}\text { Tata } \\
\text { Bahasa }\end{array}$ & $\begin{array}{c}\text { Diksi } \\
\text { dan } \\
\text { Ejaan }\end{array}$ & \multicolumn{1}{|c|}{ Keterangan } \\
\hline $\mathbf{1}$ & $\mathbf{2}$ & $\mathbf{3}$ & $\mathbf{4}$ & $\mathbf{5}$ & $\mathbf{6}$ & \multicolumn{1}{|c|}{$\mathbf{6}$} \\
\hline 1 & 201001 & 5 & 4 & 5 & 4 & 4,5 (baik) \\
\hline 2 & 201002 & 4 & 5 & 4 & 5 & 4,5 (baik) \\
\hline 3 & 201003 & 3 & 3 & 3 & 4 & 3,25 (sedang) \\
\hline 4 & 201004 & 4 & 3 & 2 & 3 & 3 (sedang) \\
\hline 5 & 201005 & 3 & 1 & 2 & 3 & 2,25 (kurang) \\
\hline 6 & 201006 & 2 & 2 & 1 & 2 & $\begin{array}{l}1,75 \text { (kurang } \\
\text { sekali) }\end{array}$ \\
\hline 7 & 201007 & 1 & 2 & 1 & 1 & $\begin{array}{l}1,25 \text { (kurang } \\
\text { sekali) }\end{array}$ \\
\hline 8 & 201008 & 2 & 1 & 1 & 2 & $\begin{array}{l}1,5 \text { (kurang } \\
\text { sekali) }\end{array}$ \\
\hline
\end{tabular}

Berdasarkan hasil tes pada siklus pertama dari 8 orang mahasiswa yang menjadi subjek penelitian, 2 orang yang mendapatkan kategori baik, 2 orang kategori sedang, 1 orang kategori kurang, dan 3 orang dengan kategori kurang sekali. Dari hasil tes tersebut dapat disimpulkan bahwa keterampilan mahasiswa menulis deskripsi masih rendah karena masih ada empat mahasiswa yang kemampuan menulis deskripsinya berkategori kurang dan kurang sekali. Untuk meningkatkan keterampilan menulis deskripsi mahasiswa dilanjutkan dengan siklus kedua.

\subsection{Deskripsi Proses Siklus Kedua}

a) Perencanaan

Siklus kedua merupakan kelanjutan dari siklus pertama. Siklus ini dilakukan untuk memperbaiki proses pembelajaran dan pencapaian tujuan pembelajaran yang dianggap masih kurang pada siklus pertama. Oleh karena itu, pada siklus kedua direncanakan dan diimplementasikan kembali penerapan model investigasi kelompok dalam pembelajaran menulis terhadap materi pembelajaran yang dianggap masih kurang. 
Perencanaan dalam penelitian tindakan kelas pada siklus kedua adalah membuat persiapan proses belajar mengajar dalam bentuk program rencana pembelajaran dan rencana kegiatan yang akan dilakukan oleh peneliti, dosen, dan mahasiswa.

\section{b) Tindakan}

Pelaksanaan pembelajaran pada siklus kedua memperlihatkan adanya peningkatan pembelajaran keterampilan menulis deskripsi mahasiswa. Peningkatan tersebut terlihat pada antusiasme mahasiswa menulis dengan berkelompok, motivasi makin me- ningkat, dan kemampuan memilih kata atau diksi yang tepat sesuai dengan tema yang telah disepakati oleh mahasiswa.

c) Refleksi

Kejadian refleksi pada siklus II ini menunjukkan bahwa mahasiswa mampu membangkitkan semangat, minat, dan kreativitasnya dalam menulis. Mahasiswa dalam proses terlihat aktif dan antusias dalam menerima pelajaran tentang menulis dengan model pembelajaran investigasi kelompok sehingga kreativitas yang ada pada dirinya dapat lebih meningkat.

d) Evaluasi

Tabel 4

Hasil Tes Siklus II Ketepatan Isi Gagasan, Ketepatan Organisasi Isi, Ketepatan Tata Bahasa, Diksi, dan Ejaan Menulis Deskripsi Mahasiswa Sastra Indonesia Angkatan 2010

\begin{tabular}{|c|c|c|c|c|c|c|}
\hline No. & $\begin{array}{c}\text { Kode } \\
\text { Subjek }\end{array}$ & $\begin{array}{c}\text { Isi } \\
\text { Gagasan }\end{array}$ & $\begin{array}{c}\text { Organisasi } \\
\text { Isi }\end{array}$ & $\begin{array}{c}\text { Tata } \\
\text { Bahasa }\end{array}$ & $\begin{array}{c}\text { Diksi dan } \\
\text { Ejaan }\end{array}$ & Keterangan \\
\hline $\mathbf{1}$ & $\mathbf{2}$ & $\mathbf{3}$ & $\mathbf{4}$ & $\mathbf{5}$ & $\mathbf{6}$ & $\mathbf{7}$ \\
\hline 1 & 201001 & 5 & 5 & 5 & 4 & 4,75 (baik) \\
\hline 2 & 201002 & 5 & 4 & 4 & 5 & 4,5 (baik) \\
\hline 3 & 201003 & 4 & 5 & 5 & 4 & 4,5 (baik) \\
\hline 4 & 201004 & 5 & 4 & 3 & 5 & 4,25 (baik) \\
\hline 5 & 201005 & 4 & 3 & 4 & 4 & 3,75 Sedang) \\
\hline 6 & 201006 & 3 & 4 & 3 & 3 & 3,25 (sedang) \\
\hline 7 & 201007 & 3 & 3 & 4 & 3 & 3,25 (sedang) \\
\hline 8 & 201008 & 4 & 3 & 5 & 3 & 3,75 (sedang) \\
\hline
\end{tabular}

Hasil tes keterampilan menulis deskripsi mahasiswa pada siklus kedua mengalami peningkatan yang baik. Berdasarkan hasil tes yang telah dilakukan terhadap 8 mahasiswa yang menjadi subjek penelitian, 4 orang berkategori baik dan 4 orang berkategori sedang. Sesuai dengan hasil tes tersebut dapat disimpulkan bahwa kemampuan menulis desksripsi mahasiswa pada siklus kedua sudah berhasil dengan mengguna- kan model investigasi kelompok. Oleh karena itu, PTK berakhir pada siklus dua.

\section{Penutup}

\subsection{Simpulan}

Berdasarkan hasil penelitian dapat disimpulkan bahwa hasil pratindakan tentang isi gagasan, organisasi isi, tata bahasa, diksi, dan ejaan dalam menulis deskripsi masih 
tergolong kurang sekali hingga ke sedang. Setelah tindakan dilakukan dengan penerapan model investigasi kelompok, pembelajaran menulis deskripsi menunjukkan adanya peningkatan kategori sedang hingga baik. Kegiatan PTK dilaksanakan selama dua siklus. Masing-masing siklus dilaksanakan dengan tiga kali pertemuan. Hasil penelitian menunjukkan adanya peningkatan keterampilan menulis deskripsi mahasiswa Sastra Indonesia dengan menggunakan model investigasi kelompok.

\subsection{Saran}

Berdasarkan simpulan yang telah dikemukakan dapat diajukan saran agar dosen Sastra Indonesia dapat menerapkan investigasi kelompok yang diarahkan ke dalam aktivitas menulis proses dalam pembelajaran menulis deskripsi khususnya dalam ketepatan isi gagasan, organisasi isi, tata bahasa, diksi, dan ejaan.

Pada pembelajaran keterampilan menulis, dosen hendaknya memberikan kesempatan kepada mahasiswa untuk lebih banyak praktik dalam hal menulis, terutama dalam persiapan untuk ujian praktik mengarang dan persiapan mahasiswa untuk mengikuti lomba karya tulis ilmiah.

Mahasiswa diharapkan lebih meningkatkan pengetahuannya tentang bahasa Indonesia, khususnya dalam bidang menulis melalui pemanfaatan model investigasi kelompok dalam meningkatkan pembelajaran menulis deskripsi.

\section{Daftar Pustaka}

Akhadiah, Sabarti dkk. 1998. Kemampuan Menulis Bahasa Indonesia. Jakarta: Erlangga.

Cox, Carole. 1998. Teaching Language Arts. A Student-and Response-Centered Classroom. California State Univercity, Long Beach: Allyin and Bacon.

Ibrahim, Muslimin. 2006. Pembelajaran Kooperatif. Surabaya: UNESA University Press.
Kadir K, Abdul. 2005. Pengembangan Model Pembelajaran Menulis Deskriptif Siswa Kelas II SMP Kemala Bayangkari Disamakan Makasar. Tesis tidak diterbitkan. Makassar: Program pascasarjana Universitas Negeri Makassar.

Kunandar. 2008. Langkah Mudah Penelitian Tindakan Kelas sebagai Pengembangan Profesi Guru. Jakarta: Rajawali Press.

Laboh. 2005. Strategi Pembelajaran Menulis Kreatif pada Siswa Madrasah Aliyah di Kota Kendari. Tesis tidak diterbitkan. Makassar: Program Pascasarjana Universitas Negeri Makassar.

Miles, B.M., \& Huberman, A.M.1992. Analisis Data Kualitatif. Terjemahan Tjetjep

Rohendi Rohidi. Jakarta: Universitas Indonesia (UI-Press)

Nurgiantoro, Burhan. 2009. Penilaian dalam Pengajaran Bahasa dan Sastra. Yogyakarta: BPFE.

Pappas, C.C. , Kiefer B. Z., \& Levstik L.S. 1995. An Integrated Language Perspective In the Elementary School. New York: Longman Publisher.

Slavin, Robert E. 1995. Cooperative Learning. Second Edition. Massachusets: Allyn \& Bacon.

Smalley, Regina E., dkk. 2001. Refining Compotision Skill: Rhetoric and Grammar. Boston: Heinle \& Heinle Publishers. Sukidin, dkk. 2002. Manajemen Penelitian Tindakan Kelas. Tanpa Kota: Insan Cendikia.

Suparno \& Yunus, M. 2002. Keterampilan Dasar Menulis. Jakarta: Universitas Terbuka, Depdiknas.

Syafi' ie. I. 1988. Retorika dalam Menulis. Jakarta: Depdikbud.

Temple, C. dkk. 1988. The Beginnings of Writing. Boston, Massachusetts: Allyn and Bacon, Inc.

Tompkins, Gail E. 1994. Teaching Writing Process and Product. New York: Harcourt. 